\title{
ФИЗИОЛОГИЧЕСКИЕ МЕХАНИЗМЫ ВОЗДЕЙСТВИЯ НИЗКОИНТЕНСИВНОГО ЛАЗЕРНОГО ИЗЛУЧЕНИЯ НА СПЕЦИАЛЬНУЮ ФИЗИЧЕСКУЮ РАБОТОСПОСОБНОСТЬ ВЫСОКОКВАЛИФИЦИРОВАННЫХ СПОРТСМЕНОВ
}

Т. М. Брук', П. А. Терехов ${ }^{1}$, Ф. Б. Литвин ${ }^{1}$, С. В. Верлин ${ }^{2}$

${ }^{1}$ Смоленская государственная академия физической культуры, спорта и туризма, Смоленск, Россия

2 Медико-восстановительный центр Государственного училища олимпийского резерва, Бронницы, Московская область, Россия

В условиях ужесточения борьбы с допингом и ограничения использования синтетических фармпрепаратов ведется поиск эффективных средств для повышения физической работоспособности и ускорения восстановления спортсменов. Одним из таких средств является воздействие низкоинтенсивным лазерным излучением (НИЛИ). Целью настоящего исследования было изучение физиологического ответа функциональных систем высококвалисицированных гребцов-академистов (женщины) на курсовое воздействие НИЛИ. Для наблюдения за организмом спортсменок использовали лазерную допплеровскую флоуметрию (ЛДФ), математический анализ сердечного ритма, нейроэнергокартирование, а также педагогическое тестирование с использованием тренажера Concept 2. После освечивания шеи в области проекции сонных артерий импульсным инфракрасным НИЛИ наблюдали повышение показателя перфузии крови на 38\% ( $<$ 0,05), показателя утилизации кислорода клетками на 48\% ( $<$ < 0,05), а также снижение показателя сатурации гемоглобина кислородом на 16\% ( $<$ < 0,05). В результате применения НИЛИ происходило повышение активности автономного механизма регуляции с ростом мощности спектра колебаний ритма сердца (ТP) на 41\% (p<0,05), мощности высокочастотных колебаний (НF) - на 73\% ( $p<0,05)$, росло влияние центрального механизма со снижением амплитуды моды (АМо) на $71 \%$ ( $p<0,05)$, индекса напряжения (ИН) - на 175\% ( $p<0,05)$. Воздействие НИЛИ способствовало повышению эффективности доставки кислорода в отдельные области коры больших полушарий с ростом уровня постоянных потенциалов (УПП). Благодаря воздействию НИЛИ на 3,32\% (p > 0,05) выросла скорость «прохождения» спортсменками дистанции 2000 м. Обнаруженные эффекты применения НИЛИ позволяют расширить спектр физиотерапевтических средств, способствующих повышению специальной физической работоспособности спортсменов и ускорению восстановления.

Ключевые слова: НИЛИ, вариабельность сердечного ритма, микроциркуляция, нейроэнергокартирование, спортсмены, работоспособность

Информация о вкладе авторов: Т. М. Брук - анализ функционального состояния мозга (нейроэнергокартирование), проведение лазерных процедур; П. А. Терехов - оценка специальной физической подготовленности, статистическая обработка результатов, подготовка рукописи; Ф. Б. Литвин изучение процессов микрогемоциркуляции, вариабельности сердечного ритма, подготовка рукописи; С. В. Верлин - отбор участников исследования.

Соблюдение этических стандартов: исследование одобрено этическим комитетом ФГБОУ ВО «СГАФКСТ» (протокол № 67 от 9 сентября 2018 г.). Все спортсменки подписали добровольное информированное согласие на участие в исследовании.

$\triangle$ Для корреспонденции: Павел Александрович Терехов

ул. Кирова, д. 42 А, кв. 11.04, г. Смоленск, 214018; terechov_86@mail.ru

Статья получена: 30.09.2019 Статья принята к печати: 21.10.2019 Опубликована онлайн: 30.10.2019

DOI: $10.24075 /$ vrgmu.2019.071

\section{PHYSIOLOGICAL MECHANISMS OF THE LOW-INTENSITY LASER RADIATION IMPACT ON THE HIGHLY QUALIFIED ATHLETES' SPECIAL PHYSICAL PERFORMANCE}

Bruk TM¹, Terekhov PA ${ }^{1} \otimes$, Litvin FB ${ }^{1}$, Verlin $\mathrm{SV}^{2}$

${ }^{1}$ Smolensk State Academy of Physical Culture, Sport and Tourism, Smolensk, Russia

2 Rehabilitation Center of the State School of the Olympic reserve, Bronnitsy, Moscow region, Russia

In the context of strengthening the fight against doping and limiting the use of synthetic pharmaceuticals, the effective remedies to increase physical performance and accelerate the recovery of athletes are being sought. One of such remedies is exposure to low-level laser radiation (LLLR, LLLT). The study was aimed to investigate the physiological response of highly qualified female rowers' functional systems to the LLLR irradiation course. To monitor the body of athletes, we used laser Doppler flowmetry (LDF), mathematical analysis of heart rate, neuroenergy mapping, as well as pedagogical testing using the Concept 2 simulator. After irradiation of the neck in the projection of the carotid arteries with pulsed infrared LLLR, the blood perfusion rate increased by $38 \%(p<0.05)$ and cell oxygen utilization rate increased by $48 \%(p<0.05)$. The decrease in the hemoglobin oxygen saturation by $16 \%(p<0.05)$ was also observed. Due to LLLT, the activity of the autonomous regulation mechanism increased with an increase in the total power of the heart rate variability spectrum (TP) by $41 \%(p<0.05)$, and in highfrequency power (HF) by 73\% ( $p<0.05)$. The influence of central mechanism decreased with a decrease in amplitude mode (AMo) by $71 \%(p<0.05)$, and in stress-index (SI) by 175\% ( $p<0.05)$. Irradiation by LLLR promoted the efficiency of oxygen delivery to certain cerebral cortex areas with the increase of SPL. After LLLT, the speed of 2000 meters distance "passing" by athletes also increased by $3.32 \%$ ( $p>0.05)$. The discovered effects of LLLT allow one to expand the range of physiotherapeutic agents that enhance the special physical performance of athletes and accelerate recovery.

Keywords: LLLR (LLLT), heart rate variability, microcirculation, neuroenergy mapping, athletes, physical performance

Author contribution: Bruk TM — analysis of brain function (neuroenergy mapping), laser therapy; Terekhov PA — physical fitness assessment, statistical analysis of the results, manuscript writing; Litvin FB — study of microcirculation and heart rate variability, manuscript writing; Verlin SV — selection of study participants.

Compliance with ethical standards: the study was approved by the Local Ethics Committee of Smolensk State Academy of Physical Culture, Sport and Tourism (protocol № 67 dated September 9, 2018). Informed consent was obtained from all study participants.

$\triangle$ Correspondence should be addressed: Pavel A. Terekhov Kirova, 42 A, kv. 11.04, Smolensk, 214018; terechov_86@mail.ru

Received: 30.09.2019 Accepted: 21.10.2019 Published online: 30.10.2019

DOI: $10.24075 /$ brsmu.2019.071

Часто для достижения рекордных показателей высококвалифицированные спортсмены работают на пределе функциональных возможностей организма, что нередко сопровождается нарушением гомеостаза. Одним из путей сохранения гомеостаза является расширение адаптационных границ органов и систем, обеспечивающих ответную 
реакцию организма на тренировочные и соревновательные физические нагрузки, что, в итоге, обеспечивает достижение приспособительного результата [1].

Согласно литературным данным, в результате поглощения энергии низкоинтенсивного лазерного излучения (НИЛИ) происходит ее трансформация в биологические реакции на всех уровнях организации живого организма, которые запускают процессы саморегуляции и самовосстановления нарушенного гомеостаза [2-5]. В частности, под воздействием НИЛИ происходит активация ферментов антиоксидантной защиты, усиливается метаболизм клеток, стабилизируются биомембраны. Воздействие НИЛИ на эластичность мембран эритроцитов способствует их проникновению в капилляры микроциркуляторного русла, а стимуляция аэробной фазы энергетического обмена с включением в него недоокисленных метаболитов гликолиза и продуктов окисления липидов через опосредованный мембранный механизм приводит к насыщению кислородом венозной крови и улучшению микроциркуляции [6]. При этом недостаточно изученными остаются вопросы влияния НИЛИ на микроциркуляторно-тканевые отношения [7].

Лазерная терапия является важнейшей составляющей современного медико-биологического обеспечения спорта высших достижений практически на всех этапах подготовки спортсменов. Всестороннее системное наблюдение за спортсменами с использованием комплекса информативных и легко воспроизводимых в любых условиях способов и методов оперативной оценки состояния организма (в том числе биохимических и гематологических показателей, показателей лазерной допплеровской флоуметрии (ЛДФ), а также данных вариабельности сердечного ритма (ВСР), нейроэнергокартирования (НЭК) и т. д.) позволяет своевременно и качественно осуществлять коррекцию гомеостаза для адекватного формирования не переходящих грань патологии процессов утомления и ускорения процессов восстановления.

Исследователями установлено потенцирующее воздействие НИЛИ на физическую работоспособность спортсменов различной квалисикации, занимающихся разными видами спорта. При воздействии НИЛИ на биологически активные точки было выявлено повышение показателя аэробной работоспособности у 80\% футболистов с последующим ростом объема произведенной механической работы [8]. Существенное увеличение абсолютных и относительных величин PWC170 после воздействия НИЛИ было получено у спортсменов циклических видов спорта. Непродолжительное воздействие НИЛИ не вызывало значимых изменений в биохимическом составе крови, но повышало активность парасимпатических влияний на сердечный ритм [9, 10]. Под влиянием НИЛИ изменялся гуморально-гормональный статус организма спортсменов. В частности, было показано увеличение концентрации бета-эндорфина, глюкокортикоидов, трийодтиронина, тироксина у спортсменов игровых видов спорта, лыжников-гонщиков $[11,12]$

Описаны системные механизмы, обеспечивающие эффекты лазерной стимуляции в комплексной подготовке хоккеистов. Позитивные структурно-функциональные изменения организма хоккеистов и пловцов приводят к выраженному повышению его тренированности [13, 14].

Целью настоящего исследования было изучить физиологический ответ важнейших функциональных систем организма высококвалифицированных гребцовакадемистов (женщины) на курсовое воздействие НИЛИ
В специально-подготовительном периоде годичного цикла спортивной подготовки. Перед нами стояли следующие задачи: оценить влияние НИЛИ на систему микрогемоциркуляции, выявить изменения в регуляции сердечного ритма, изучить влияние на метаболическую активность нейронов коры больших полушарий, а также оценить уровень физической работоспособности высококвалифицированных спортсменов.

\section{ПАЦИЕНТЫ И МЕТОДЫ}

Исследование было проведено в октябре 2018 г., в нем приняли участие 24 высококвалифицированных гребцаакадемиста (женщины, учащиеся Государственного училища олимпийского резерва г. Бронницы Московской области). Исследование проходило на базе учебнотренировочного центра.

Испытуемые были разделены на основную (ОГ) и контрольную (КГ) группы. Основную группу составили 12 спортсменок. Критерии включения: уровень квалисикации мастер спорта (МC); членство в сборной команде Московской области. Критерии исключения: низкая квалификация спортсменки, острый период заболевания. В контрольную группу вошли 12 спортсменок (МС), не прошедших квалисрикационный отбор в сборную команду. Представители обеих групп занимались по единой тренировочной программе.

Исследование проводили в два этапа. На первом этапе изучали функциональное состояние отдельных систем организма и физическую подготовленность спортсменок ОГ и КГ до воздействия НИЛИ. Далее спортсменки обеих групп в недельном тренировочном цикле выполняли специальную тренировочную программу по подготовке к соревновательному сезону.

Спортсменок ОГ утром до начала тренировки в течение 7 дней подвергали воздействию НИЛИ, освечивая шею симметрично с обеих сторон в области сонного треугольника с помощью двухканального лазерного терапевтического аппарата «Узор-А-2К» («Восход»; Россия). Длина волны излучения составляла 0,89 \pm 0,02 мкм; режим излучения импульсный, частота повторения импульсов - 1500 Гц, время экспозиции - 10 мин. Спортсменкам КГ проводили «Мнимую» процедуру воздействия НИЛИ без включения излучающих головок аппарата «Узор-А-2K». После лазерной процедуры проводили повторную регистрацию изучаемых показателей.

Оценку вариабельности сердечного ритма (ВСР) атлетов проводили с помощью аппарата «Варикард 2.51» («ИВНМТ «РАMEHА»; Россия). Запись кардиоинтервалограмм продолжительностью 5 мин проводили по общепринятой методике в положении сидя. Оценивали следующие количественные показатели ВСР: ЧСС, показатели, характеризующие активность автономного (мощность спектра колебаний ритма сердца, ТР; мощность высокочастотных колебаний, HF) и центрального механизмов регуляции (мощность низкочастотных колебаний, LF; мощность ультранизкочастотных колебаний, VLF; амплитуда моды, АMo), показатель преобладания центральных механизмов регуляции над автономным (индекс напряжения, ИН).

В качестве регистрирующей аппаратуры для изучения микрогемоциркуляции применяли промышленный лазерный анализатор капиллярного кровотока ЛАКК-М (НПП «Лазма»; Россия), после чего анализировали параметр микроциркуляции (ПМ) в перфузионных единицах 
(перф. ед.). Амплитудно-частотный анализ осцилляций кровотока выполняли с помощью программы вейвлетанализа LDF3.0.2.384 (НПП «Лазма»; Россия).

Вклад активного механизма в формирование сосудистого тонуса оценивали по величине амплитуды нейрогенных (Ан), миогенных (Ам) и эндотелийзависимых (Аэ) колебаний (перф. ед.). Вклад пассивного механизма оценивали по величине амплитуды дыхательных (Ад) и пульсовых (Ап) колебаний (перф. ед.). Применяя указанный прибор, методом оптической тканевой оксиметрии

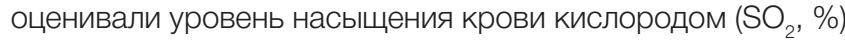
и величину удельного потребления кислорода (U, усл. ед.). По показателям уровня постоянных потенциалов (УПП) оценивали метаболическую активность ткани мозга в нижнелобной, центральной, затылочной, левой и правой височных областях.

Для топографического картирования электрической активности мозга применяли пятиканальный аппаратнопрограммный комплекс «НЕЙРО-КМ» (научно-медицинская фирма «СТАТОКИН»; Россия) по стандартной методике [15]. В качестве показателей специальной физической подготовленности учитывали время «прохождения» дистанции 2000 м на специальном гребном тренажере «Concept 2 Model D» (PM5; Китай). Тест выполняли в зале в условиях постоянной температуры и освещенности.

Статистическую обработку полученных результатов проводили с помощью программного обеспечения IBM
SPSS Statistics 19 для Windows (StatSoft, Inc.; США). Для сравнения исследуемых показателей у спортсменок ОГ и КГ применяли U-критерий Манна-Уитни. Для сравнения показателей в ОГ и КГ с мнимым эффектом НИЛИ, а также с показателями после лазерного воздействия использовали Т-критерий Уилкоксона. Различия считали достоверными при $p<0,05$.

\section{РЕЗУЛЬТАТЫ ИССЛЕДОВАНИЯ}

Чрескожная лазерная стимуляция в условиях стандартных тренировочных нагрузок способствует расширению функциональных возможностей организма на разных уровнях организации, от клеточного до системного. Нами была изучена динамика процессов, происходивших в микрососудистом русле после курсового воздействия НИЛИ.

У спортсменок ОГ по сравнению с исходным уровнем на 38\% достоверно повысился уровень перфузии ( $>$ < 0,05), у спортсменок КГ показатель микроциркуляции за это время увеличился на $5 \%$ ( $>$ > 0,05) (табл. 1). Веским доказательством биостимулирующего эффекта НИЛИ на обмен кислорода у спортсменок ОГ было снижение на 14\% $\mathrm{SO}_{2}$ в микроциркуляторном русле ( $p<0,05)$ при наличии тенденции к увеличению $\mathrm{SO}_{2}$ в $\mathrm{K} Г$ на $2 \%(p>0,05)$. На диффузию кислорода из крови в ткани указывало достоверное повышение на 49\% $(p<0,05)$

Таблица 1. Показатели микроциркуляции крови у высококвалифицированных гребцов-академистов (женщины) на отдельных этапах исследования (М \pm m)

\begin{tabular}{|c|c|c|c|c|c|}
\hline \multirow{2}{*}{$\begin{array}{l}\text { № } \\
\text { ח/ח }\end{array}$} & \multirow{2}{*}{ Показатели } & \multirow{2}{*}{ Группы } & \multicolumn{2}{|c|}{ Этапы исследования } & \multirow{2}{*}{$p<0,05$} \\
\hline & & & 1 & ॥ & \\
\hline \multirow{3}{*}{1} & \multirow{3}{*}{ ПМ, перф. ед. } & ОГ & $12,92 \pm 1,61$ & $17,86 \pm 2,05$ & * \\
\hline & & $\mathrm{K} \Gamma$ & $11,50 \pm 1,34$ & $12,07 \pm 1,80$ & \\
\hline & & $p$ & $>0,05$ & ${ }^{* *}<0,05$ & \\
\hline \multirow{3}{*}{2} & \multirow{3}{*}{$\mathrm{SO}_{2}, \%$} & ОГ & $80,2 \pm 4,04$ & $69,1 \pm 3,72$ & * \\
\hline & & $\mathrm{K} \Gamma$ & $81,2 \pm 4,56$ & $82,9 \pm 5,17$ & \\
\hline & & $p$ & $>0,05$ & ${ }^{* *}<0,05$ & \\
\hline \multirow{3}{*}{3} & \multirow{3}{*}{ U, усл. ед. } & Ог & $1,87 \pm 0,10$ & $2,79 \pm 0,16$ & * \\
\hline & & $\mathrm{K} \Gamma$ & $1,68 \pm 0,08$ & $1,70 \pm 0,12$ & \\
\hline & & $p$ & $>0,05$ & ${ }^{* *}<0,05$ & \\
\hline \multirow{3}{*}{4} & \multirow{3}{*}{ Ап, перф. ед. } & Ог & $13,25 \pm 1,84$ & $18,01 \pm 2,59$ & * \\
\hline & & $\mathrm{K} \Gamma$ & $15,38 \pm 2,34$ & $13,79 \pm 1,83$ & \\
\hline & & $p$ & $>0,05$ & $>0,05$ & \\
\hline \multirow{3}{*}{5} & \multirow{3}{*}{ Ад, перф. ед. } & ог & $20,06 \pm 2,93$ & $22,57 \pm 3,12$ & \\
\hline & & $\mathrm{K} \Gamma$ & $17,84 \pm 2,50$ & $23,19 \pm 4,01$ & \\
\hline & & $p$ & $>0,05$ & $>0,05$ & \\
\hline \multirow{3}{*}{6} & \multirow{3}{*}{ Ам, перф. ед. } & ог & $25,70 \pm 3,10$ & $39,41 \pm 4,80$ & * \\
\hline & & $\mathrm{K} \Gamma$ & $26,24 \pm 4,42$ & $27,11 \pm 3,86$ & \\
\hline & & $p$ & $>0,05$ & ${ }^{* *}<0,05$ & \\
\hline \multirow{3}{*}{7} & \multirow{3}{*}{ Ан, перф. ед. } & ог & $31,93 \pm 2,72$ & $44,69 \pm 4,90$ & * \\
\hline & & $\mathrm{K} \Gamma$ & $29,13 \pm 3,15$ & $30,42 \pm 3,16$ & \\
\hline & & $p$ & $>0,05$ & ${ }^{* *}<0,05$ & \\
\hline \multirow{3}{*}{8} & \multirow{3}{*}{ Аэ, перф. ед. } & ог & $35,78 \pm 4,96$ & $58,00 \pm 5,70$ & * \\
\hline & & $\mathrm{K} \Gamma$ & $30,85 \pm 3,75$ & $33,55 \pm 4,28$ & \\
\hline & & $p$ & $>0,05$ & ${ }^{* *}<0,05$ & \\
\hline
\end{tabular}

Примечание: ПМ - параметр микроциркуляции; $\mathrm{SO}_{2}$ - насыщение крови кислородом в тканях кожи; U - потребление кислорода; Ап - пульсовые колебания значений ПМ; Ад — дыхательные колебания значений ПМ; Ам - миогенные колебания значений ПМ; Ан — нейрогенные колебания значений ПМ; Аэ - эндотелиальные колебания значений ПМ. ** — межгрупповые различия; * — внутригрупповые различия при $p<0,05$. 
расчетного показателя утилизации кислорода тканями. У спортсменок КГ рост данного показателя фактически отсутствовал (1\%, $p>0,05)$.

В нашем исследовании у спортсменок ОГ тонус миоцитов снижался на 53\% ( $p<0,05)$, тем самым увеличивая просвет сосудов микроциркуляторного русла. Кроме того, артериолы увеличивали свой просвет в результате снижения активности симпатических нервов вегетативной нервной системы, окончания которых иннервировали гладкомышечные клетки среднего слоя сосудов. По данным вейвлет-анализа, показатель нейрогенного тонуса снижался на 40\% ( $p<0,05)$. Под влиянием НИЛИ повышалась пропускная способность обменного звена микроциркуляторного русла, обусловленная вазодилатацией микрососудов разного диаметра.

На уровне вегетативной нервной системы (BНC) курсовое воздействие НИЛИ снижало активность симпатического отдела, одновременно усиливая влияние на сердце парасимпатического отдела ВНС, оказывающего трофотропный восстановительный эффект (табл. 2). В процессе исследования было установлено, что ИН снизился на 174\%, АМо - на 48\% ( $p<0,05)$, на 41\% достоверно повысились показатели ТР и частных спектральных характеристик (на 121\% LF-спектра и на 73\% HF-спектра, p < 0,05). Обращает на себя внимание рост на 75\% спектрального показателя VLF, который характеризует работу корково-гуморальных центров.

В отсутствие физиотерапевтического воздействия у спортсменок КГ в ходе тренировочных нагрузок сохранялась высокая активность симпатических влияний с тенденцией на снижение влияния блуждающего нерва на ритм сердца. Высокая активность симпато-адреналовой системы усиливала энергодефицитное состояние. Благодаря лазерным процедурам у спортсменок ОГ в период восстановления между тренировочными занятиями усиливался анаболизм в тканях, что обеспечивало высокую функциональную готовность организма к тренировочной деятельности. При этом у спортсменок КГ сохранялся повышенный катаболизм, что вызывало накопление утомления из-за недовосстановления организма после очередной тренировки.

Воздействие НИЛИ опосредованно стимулирует функциональные адаптационные изменения в нейронах коры больших полушарий. После курсового воздействия НИЛИ у высококвалифицированных спортсменок ОГ усиливалась метаболическая активность ткани мозга в исследуемых областях, о чем свидетельствует рост значений уровня постоянных потенциалов (УПП). По сравнению с исходным состоянием (табл. 3) наблюдалось увеличение показателя УПП на 94\% в лобной области, на 109\% в центральной, на 33\% в затылочной и 29\% в левой височной областях (во всех случаях $p<0,05)$.

Распределение постоянного потенциала после лазерных процедур подчиняется принципу куполообразности (табл. 3). У спортсменок КГ максимальные значения УПП зарегистрированы в затылочной $(\mathrm{Oz})$ и левой височной областях (Ts). Таким образом, нарушается «куполообразность» распределения энерготрат по отделам головного мозга, т. е. происходит некая деформация.

У гребцов-академистов КГ величина показателя УПП за время исследования тенденциозно нарастала, не достигая статистически значимого уровня различий.

Таблица 2. Показатели вариабельности сердечного ритма у высококвалифицированных гребцов-академистов (женщины) на отдельных этапах исследования $(\mathrm{M} \pm m)$

\begin{tabular}{|c|c|c|c|c|c|}
\hline \multirow{2}{*}{$\begin{array}{l}\text { № } \\
\text { п/п }\end{array}$} & \multirow{2}{*}{ Показатели } & \multirow{2}{*}{ Группы } & \multicolumn{2}{|c|}{ Этапы исследования } & \multirow{2}{*}{$p<0,05$} \\
\hline & & & 1 & II & \\
\hline \multirow{3}{*}{1} & \multirow{3}{*}{ ЧСС, уд./мин } & ог & $75,66 \pm 3,20$ & $66,94 \pm 2,04$ & * \\
\hline & & $\mathrm{K} \Gamma$ & $77,17 \pm 3,18$ & $75,67 \pm 3,25$ & \\
\hline & & $p$ & $>0,05$ & ${ }^{* *}<0,05$ & \\
\hline \multirow{3}{*}{2} & \multirow{3}{*}{ AMo, \% } & Ог & $40,10 \pm 3,55$ & $26,52 \pm 2,41$ & * \\
\hline & & $\mathrm{K} \Gamma$ & $37,92 \pm 0,91$ & $38,55 \pm 0,88$ & \\
\hline & & $p$ & $>0,05$ & $* *<0,05$ & \\
\hline \multirow{3}{*}{3} & \multirow{3}{*}{ ИН, усл. ед. } & ОГ & $167,02 \pm 19,53$ & $60,73 \pm 6,38$ & * \\
\hline & & $\mathrm{K} \Gamma$ & $126,27 \pm 13,87$ & $123,94 \pm 13,64$ & \\
\hline & & $p$ & $>0,05$ & ${ }^{* *}<0,05$ & \\
\hline \multirow{3}{*}{4} & \multirow{3}{*}{$\mathrm{TP}, \mathrm{Mc}^{2}$} & ог & $3793,11 \pm 522,24$ & $5340,14 \pm 701,02^{\star}$ & * \\
\hline & & $\mathrm{K} \Gamma$ & $1564,17 \pm 209,46$ & $1598,62 \pm 213,95$ & \\
\hline & & $p$ & ${ }^{* *}<0,05$ & ${ }^{* *}<0,05$ & \\
\hline \multirow{3}{*}{5} & \multirow{3}{*}{$\mathrm{HF}, \mathrm{MC}^{2}$} & Ог & $967,95 \pm 130,74$ & $1671,85 \pm 175,12$ & * \\
\hline & & $\mathrm{K} \Gamma$ & $877,50 \pm 120,29$ & $581,31 \pm 70,37$ & \\
\hline & & $p$ & $>0,05$ & ${ }^{* *}<0,05$ & \\
\hline \multirow{3}{*}{6} & \multirow{3}{*}{$L F, M^{2}$} & ОГ & $889,65 \pm 153,29$ & $1965,54 \pm 233,56$ & * \\
\hline & & $\mathrm{K} \Gamma$ & $473,67 \pm 50,07$ & $477,00 \pm 50,29$ & \\
\hline & & $p$ & $>0,05$ & ${ }^{* *}<0,05$ & \\
\hline \multirow{3}{*}{7} & \multirow{3}{*}{ VLF, $\mathrm{MC}^{2}$} & ог & $967,75 \pm 150,62$ & $1693,76 \pm 195,17$ & * \\
\hline & & $\mathrm{K} \Gamma$ & $519,50 \pm 79,60$ & $426,57 \pm 61,58$ & \\
\hline & & $p$ & $>0,05$ & ${ }^{* *}<0,05$ & \\
\hline
\end{tabular}

Примечание: чСС - частота сердечных сокращений; АМо - амплитуда моды; ИН - индекс напряженности; ТР - мощность спектра колебаний ритма сердца; HF — мощность высокочастотных колебаний ритма сердца; LF — мощность низкочастотных колебаний ритма сердца; VLF — мощность ультранизкочастотных колебаний ритма сердца. ${ }^{* *}$ — межгрупповые различия; * — внутригрупповые различия при $p<0,05$. 
Таким образом, после курсового воздействия НИЛИ повышался энергетический метаболизм нейронов в изученных областях коры больших полушарий.

Корректную оценку эффективности применения НИЛИ в качестве средства восстановления целесообразно проводить по динамике уровня тренированности. В настоящем исследовании уровень тренированности оценивали с помощью специфического тестирования на гребном тренажере «Concept 2». Полученные нами показатели времени «прохождения» дистанции 2000 м высококвалифицированными гребцами-академистами представлены в табл. 4. На первом этапе (исходный уровень) не было выявлено достоверных различий между значениями времени «прохождения» дистанции спортсменками обеих групп. В частности, испытуемые КГ «преодолели» дистанцию за 456,55 \pm 3,55 c, а атлеты ОГ за 454,07 $\pm 2,43$ с $(p>0,05)$.

Курсовое воздействие НИЛИ оказывает стимулирующее влияние на организм спортсменок ОГ, обеспечивая повышение скорости «прохождения» дистанции 2000 м до 435,63 \pm 2,34 с, что на 3,32\% меньше исходного показателя ( $p<0,01)$. У гребцов КГ время «прохождения» дистанции почти не меняется $(453,02 \pm 3,34$ с) ( $p>0,05)$. Следовательно, в условиях стандартно построенного тренировочного процесса курсовое воздействие НИЛИ приводит к повышению специальной физической работоспособности женщин-гребцов на этапе специальноподготовительного периода годичного цикла спортивной тренировки

\section{ОБСУЖДЕНИЕ РЕЗУЛЬТАТОВ}

Анализ полученных данных показал, что курсовое действие НИЛИ повышает функциональные возможности системы микрогемоциркуляции. Нами был зафиксирован достоверный рост перфузии, свидетельствующий о повышении метаболической активности на клеточном и тканевом уровнях. В основе повышения интенсивности микрокровотока лежит вазодилатация микрососудов, обусловленная работой внешних и внутренних механизмов регуляции [16-18].

Из внутренних механизмов наибольший вклад В повышение пропускной способности сосудов микроциркуляторного русла обеспечивает эндотелиальный компонент. С участием эндотелиоцитов формируется вазодилататорная реакция, при которой тонус микрососудов снижается на 62\% ( $p<0,05)$. Пусковым стимулом, возникающим в ответ на воздействие лазерным излучением, является выделение $\mathrm{Ca}^{2+}$-зависимыми клетками эндотелия вазодилататора, оксида азота NO, предшественника эндотелиального фактора расслабления стенок сосудов (EDRF) [19]. Миогенный вазодилататорный эффект обусловлен снижением тонуса гладкомышечных клеток сосудистой стенки.

На уровне гладкомышечных клеток воздействие НИЛИ повышает уровень внутриклеточного цАМФ в цитозоле, что приводит к активации кальциевой АТФазы, снижению ионов кальция в цитоплазме и расслаблению гладкомышечных клеток сосудов [20].

Таблица 3. Уровень постоянных потенциалов (мВ) в различных областях коры головного мозга у высококвалисицированных гребцов-академистов (женщины) на отдельных этапах исследования $(\mathrm{M} \pm m)$

\begin{tabular}{|c|c|c|c|c|c|}
\hline \multirow{2}{*}{$\begin{array}{l}\text { № } \\
\Pi / \text { ח }\end{array}$} & \multirow{2}{*}{ Показатели } & \multirow{2}{*}{ Группы } & \multicolumn{2}{|c|}{ Этапы исследования } & \multirow{2}{*}{$p<0,05$} \\
\hline & & & 1 & ॥ & \\
\hline \multirow{3}{*}{1} & \multirow{3}{*}{ Нижнелобная область (Fz) } & ог & $7,129 \pm 0,384$ & $13,851 \pm 0,531$ & * \\
\hline & & $\mathrm{K} \Gamma$ & $5,214 \pm 0,312$ & $5,915 \pm 0,334$ & \\
\hline & & $p$ & $>0,05$ & ${ }^{* *}<0,05$ & \\
\hline \multirow{3}{*}{2} & \multirow{3}{*}{ Центральная область (Cz) } & ог & $7,277 \pm 0,390$ & $15,239 \pm 0,745$ & * \\
\hline & & $\mathrm{K} \Gamma$ & $7,315 \pm 0,411$ & $7,854 \pm 0,425$ & \\
\hline & & $p$ & ${ }^{* *}<0,05$ & $>0,05$ & \\
\hline \multirow{3}{*}{3} & \multirow{3}{*}{ Затылочная область (Oz) } & ог & $9,724 \pm 0,404$ & $12,954 \pm 0,525$ & * \\
\hline & & $\mathrm{K} \Gamma$ & $8,057 \pm 0,354$ & $8,948 \pm 0,477$ & \\
\hline & & $p$ & $>0,05$ & $>0,05$ & \\
\hline \multirow{3}{*}{4} & \multirow{3}{*}{ Левая височная область (Тs) } & ог & $10,121 \pm 0,334$ & $13,063 \pm 0,526$ & * \\
\hline & & $\mathrm{K} \Gamma$ & $10,289 \pm 0,351$ & $11,973 \pm 0,382$ & \\
\hline & & $p$ & $>0,05$ & $>0,05$ & \\
\hline
\end{tabular}

Примечание: ОГ — основная группа; КГ — контрольная группа. ** — межгрупповые различия; * — внутригрупповые различия при р < 0,05.

Таблица 4. Время «прохождения» дистанции 2000 м на тренажере «Concept 2» высококвалифицированными гребцами-академистами (женщины) на отдельных этапах исследования (M $\pm m)$

\begin{tabular}{|c|c|c|c|c|c|}
\hline \multirow{2}{*}{$\begin{array}{l}\text { № } \\
\Pi / \Pi\end{array}$} & \multirow{2}{*}{ Показатели } & \multirow{2}{*}{ Группы } & \multicolumn{2}{|c|}{ Этапы исследования } & \multirow{2}{*}{$p<0,05$} \\
\hline & & & I & II & \\
\hline \multirow{3}{*}{1} & \multirow{3}{*}{$\begin{array}{c}\text { Время «прохождения» дистанции } 2000 \text { м на тренажере } \\
\text { «Concept 2», с }\end{array}$} & ОГ & $454,07 \pm 2,43$ & $435,63 \pm 2,34$ & * \\
\hline & & $\mathrm{K} \Gamma$ & $456,55 \pm 3,55$ & $453,02 \pm 3,34$ & \\
\hline & & $p$ & $>0,05$ & ${ }^{* *}<0,01$ & \\
\hline
\end{tabular}

Примечание: ОГ — основная группа; КГ — контрольная группа. ** — межгрупповые различия; * — внутригрупповые различия при $p<0,05$. 
Выраженный эффект лазерной гемофоотостимуляции связан с влиянием низкоинтенсивного излучения на обмен веществ. Возрастает окисление энергетических материалов - глюкозы, пирувата, лактата, что ведет к улучшению микроциркуляции и утилизации кислорода в тканях [21]. Снижается показатель сатурации гемоглобина кислородом в смешанной крови микроциркуляторного русла, растет показатель удельного потребления кислорода тканями, что облегчает их метаболизм и обеспечивает энергообразование в форме АТФ в клетках [22]. Повышение функциональной активности клеток происходит, в первую очередь, вследствие кальцийзависимого повышения редокс-потенциала митохондрий, повышения их функциональной активности и синтеза АТФ [23-26]. В митохондриях под воздействием НИЛИ ускоряется перенос электронов по дыхательной цепи [26].

С позиции теории функциональных систем П. К. Анохина, для реализации организмом приспособительного эффекта привлекаются структурные и функциональные компоненть разного уровня и локализации. Локальное улучшение гомеостаза на микроциркуляторно-тканевом уровне является составной частью перестройки вегетативного баланса на системном уровне [27]. Под влиянием больших физических нагрузок нарушается оптимальное соотношение между симпатическим и парасимпатическим звеньями ВНС в пользу преобладания симпатикотонии, отражая дисбаланс реципрокных регуляторных влияний ВНС на кардиальную систему спортсмена. В таких условиях наблюдается выраженное напряжение компенсаторных механизмов сердечно-сосудистой системы, сопровождающееся дезадаптацией [28].

По результатам исследования установлено, что воздействие НИЛИ изменяет активность нервных центров, участвующих в регуляции сердечной деятельности. Исследователи отмечают, что воздействие НИЛИ активизирует работу кальций-зависимых механизмов [29]. Кальций является внутриклеточным посредником действия ряда гормонов, в первую очередь медиаторов ЦНС и ВНО [30], что предполагает участие лазер-индуцированных эффектов в нейрогуморальной регуляции. По окончании цикла процедур снижается активность симпатического отдела ВНС, повышается вклад парасимпатического отдела и снижается напряженность регуляторных процессов в целом. В целом воздействие НИЛИ способствует развертыванию трофотропных процессов, направленных на сохранение энергетических и пластических ресурсов.

Хорошо известно, что спортивная деятельность дает результаты только тогда, когда мастерство атлета отточено до автоматизма, когда минимально участие центральных регулирующих систем. Система с относительно автономными связями в силу независимости ее элементов отличается большей пластичностью, что облегчает ее приспособление к изменяющимся условиям среды, включая приспособление к условиям спортивной деятельности [31]. Увеличение числа «степеней свободы» синусового узла способствует достижению организмом функционального оптимума при выполнении нагрузки. В результате индекс напряженности $(И Н)$ снижается на 174\% ( $p<0,05)$. Динамика спектральных показателей свидетельствует о переходе на более высокий уровень адаптационных возможностей, обеспечивающих устойчивость организма спортсмена к тренировочным нагрузкам. Так, показатель роста активности автономного контура управления сердечным ритмом (HF) повышается на 73\%, центрального (LF) - на 121\%. Одновременно на $75 \%$ усиливается вклад корково-гуморальных центров управления (VLF) на фоне брадикардии. Такая спектрограмма может отражать высокие функциональные возможности организма спортсмена [32]

Повышение функционального резерва организма после курсового воздействия низкоинтенсивного магнитолазерного излучения отмечали и ранее [33, 34]. Лазерный свет выполняет регулирующую функцию по восстановлению вегетативного баланса, оказывая сдерживающее влияние на активность симпатоадреналовой системы [35]. Получены доказательства взаимосвязи между повышенной относительной мощностью спектра сердечного ритма в диапазоне VLF частоты с изменением частотных и временных параметров ритмической активности головного мозга [36]. Ритмическую активность головного мозга отмечали в фронтальной, теменной и затылочной областях мозга.

Некоторые исследователи отмечают, что основной характеристикой нормального энергообмена выступает принцип куполообразности, при котором максимальные значения потенциала регистрируются в центральном отведении $(\mathrm{Cz})$ и плавно снижаются к периферии [37]. Очевидно, сдвиг УПП в затылочную и левую височную области может быть связан с усилением функциональной активности неспецифических ретикуло-лимбикокортикальных нейронных связей [38].

Дисбаланс регуляторных влияний со стороны высшей нервной деятельности, зависящих от головного мозга и его коры, приводит к нарушению скорости условнореслекторных реакций, нарушению взаимодействия между первой и второй сигнальными системами, сопровождается психоэмоциональными и поведенческими отклонениями [39]. Однако механизмы адаптациогенеза корковых нейронов спортсменов под влиянием предельно высоких физических нагрузок остаются недостаточно исследованными. Результаты выполненного нами исследования по изучению метаболической активности нейронов в отдельных областях коры больших полушарий после курсового воздействия НИЛИ демонстрируют улучшение в 1,3-2 раза величины уровня постоянного потенциала.

Формирование структурно-фуунцциональных адаптационных изменений в организме под влиянием НИЛИ способствует повышению физической работоспособности и тренированности высококвалифицированных гребцовакадемистов. Взаимодействие низкоэнергетического лазерного излучения с организмом позволяет создать высокоэффективную методику использования лазерных терапевтических аппаратов в комплексе мероприятий по повышению специальной работоспособности, тренированности и спортивной результативности атлетов [40].

\section{ВЫВОДЫ}

Проведенные нами исследования показали, что воздействие НИЛИ улучшает функциональное состояние организма спортсменов и повышает эффективность спортивной подготовки на тренировочном (подготовительном) этапе. Системный ответ на воздействие НИЛИ сопровождало увеличение перфузии обменного звена микроциркуляторного русла, облегчение диффузии кислорода из крови в ткани и рост эффективности использования кислорода в клетке. В значительной степени усиление микрокровотока было обеспечено дополнительным притоком крови из магистральных сосудов. После курсового воздействия НИЛИ повышалась метаболическая активность нейронов 
отдельных областей коры больших полушарий. Таким образом, в результате лазерного воздействия возрастает адаптационная устойчивость организма, расширяются его функциональные возможности, что способствует повышению специальной физической работоспособности спортсменов и ускорению восстановления.

\section{Литература}

1. Анохин П. К. Принципиальные вопросы общей теории функциональных систем. Принципы системной организации функций. М.: Наука, 1973; с. 5-61.

2. Кузнецова Т. Н., Павлов С. Е. Методика применения физиотерапевтических средств (низкоэнергетических ИКлазеров) в тренировочном процессе пловцов. Методическая разработка для преподавателей, аспирантов и студентов РГАФК. М.: РГАФК, 1997; 52 с.

3. Доровских В. А., Бородин Е. А., Бородина Г. П. и др. Влияние низкоэнергетических лазеров на свободнорадикальное окисление глюкозо-6-фросфат дегидрогеназы и каталазь эритроцитов. В сборнике: Материалы Международного конгресса «Лазер и здоровье-99»; Москва, 1999; 435-6.

4. Козель А. И., Попов Г. К. Механизм действия лазерного облучения на тканевом и клеточном уровне. Вестник РАМН. 2000; (2): 41-3.

5. Улащик В. С. Анализ механизмов первичного действия низкоинтенсивного лазерного излучения на организм. Здравоохранение (Минск). 2016; (6): 41-51.

6. Потемкин Л. А. Медико-биологическое обеспечение и квантовая медицина спорта высших достижений. М.: Изд-во ЗАО «МИЛТА-ПКПГИТ», 2001; 135 с

7. Крупаткин А. И., Сидоров В. В. Функциональная диагностика состояния микроциркуляторно-тканевых систем: Колебания, информация, нелинейность. Руководство для врачей. М.: ЛИБРОКОМ, 2014; 498 с.

8. Богослова Т. В. Влияние низкоинтенсивного лазерного излучения на фризическую работоспособность студентов института физической культуры [диссертация]. Ярославль, 2004.

9. Осипова Н. В. Сравнительная характеристика влияния низкоинтенсивного лазерного излучения на уровень физической работоспособности студентов различных специализаций спортивного вуза [диссертация]. СПб., 2008.

10. Прокопюк 3. Н. Устойчивость организма спортсменов к гипоксии и ее коррекция низкоинтенсивным лазерным воздействием [диссертация]. Смоленск, 2010.

11. Лиске М. В. Динамика гормонального статуса спортсменов различной квалификации, выполняющих физическую нагрузку умеренной мощности на фоне лазерного воздействия [диссертация]. Курск, 2009.

12. Волкова А. А. Влияние низкоинтенсивного лазерного излучения на функцииональное состояние организма лыжников-гонщиков [диссертация]. Смоленск, 2011.

13. Павлов С. Е., Разумов А. Н., Павлов А. С. Лазерная стимуляция В медико-биологическом обеспечении подготовки квалифицированных спортсменов. М.: Спорт, 2017; 536 с.

14. Павлов С. Е., Павлов А. С., Петров А. А. Особенности динамики среднегрупповых показателей дисперсионных характеристик функционирования миокарда хоккеистов, использовавших В предстартовой подготовке метод лазерной стимуляции спортивной работоспособности. В сборнике: Олимпийский бюллетень № 15, сост. Мельникова Н. Ю., Трескин А. В., Леонтьева Н. С., Никифорова А. Ю.; М.: Изд-во ЗАО «Олимпийская панорама», 2014; 247-51.

15. Фокин В. Ф., Пономарёва Н. В., Кунцевич Г. И. Электрофизиологические корреляты скорости движения крови по средней мозговой артерии здорового человека. Вестник РАМН. 2013; (10): 57-60.

16. Bollinger $\mathrm{A}$. Is high-frequency flux motion due to respiration or to vasomotion activity? In: A. Bollinger, et al. Vasomotion and flow motion. Prog Appl Microcirculation Basel, Karger. 1993; (20) $52-58$.
17. Fagrell B. Problems using laser Doppler on the skin in clinical practice. Laser Doppler.- London - Los Angeles - Nicosia: Med Orion Publishing Company. 1994; 49-54.

18. Федорович А. А. ВЭБ-капилляроскопия - новые возможности мониторирования капиллярного кровотока в коже человека. В сборнике: Материалы XII международной научной конференции «Микроциркуляция и гемореология»; 01-03 июля 2019 г.; Ярославль: Канцлер 2019: 11

19. Murrey RK et al. Harper's Biochemistry. Appleton \& Lange, 1996; $700 \mathrm{p}$.

20. Daniolos A, Lerner AB, Lerner MR. Action of light on frog pigment cells in culture. Pigment Cell Res. 1990; 3 (1): 38-43.

21. Тамбовский А. Н., Сидоренко Т. А. Некоторые результать применения внетренировочного средства в процессе подготовки гребцов. Ученые записки университета имени П. Ф. Лесгафта. 2015; 5 (123): 182-85.

22. Кару Т. И. Первичные и вторичные клеточные механизмы лазерной терапии. В книге: Москвин С. В., Буйлин В. А., редакторы. Низкоинтенсивная лазерная терапия. М.: Техника, 2000; c. 71-94.

23. Мальцев А. П. Механизмы действия лазерного излучения на прокариотические клетки. Международный студенческий научный вестник. 2016; (6): 23.

24. Filippin L, Magalhães PJ, Di Benedetto G et al. Stable interactions between mitochondria and endoplasmic reticulum allow rapid accumulation of calcium in a subpopulation of mitochondria. J Biol Chem. 2003; 278 (40): 39224-34.

25. Schaffer M, Sroka R, Fuchs $C$ et al. Biomodulative effects induced by $805 \mathrm{~nm}$ laser light irradiation of normal and tumor cells. Journal of Photochemistry and Photobiology B: Biology. 1997; 40 (3): 253-57.

26. Елисеенко В. И. Механизмы взаимодействия низкоэнергетического лазерного излучения ИК-спектра с биологическими тканями В сборнике: Лазеры и аэроионы в медицине под ред. Евстигнеева А. Р., Каплана М. А; КалугаОбнинск, 1997; 71-2.

27. Крупаткин А. И. Неинвазивная оценка тканевого дыхания у человека с использованием вейвлет-анализа колебаний сатурации крови кислородом и кровотока в микрососудах кожи. Физиология человека. 2012; 38 (4): 67-73.

28. Гаврилова Е. А., Ларинцева О. С. Факторы риска внезапной сердечной смерти спортсменов на разных этапах спортивной подготовки по данным кардиологического обследования. Спортивная медицина: наука и практика. 2018; (2): 33-6.

29. Москвин С. В., Федорова Т. А., Фотеева Т. С. Плазмаферез и лазерное освечивание крови. М.-Тверь: ООО «Изд-во «Триада», 2018; 416 c

30. Греннер Д. Гормоны, регулирующие метаболизм кальция. В книге: Р. Марри, Д Греннер и др., редакторы. Биохимия человека, том 2. М.: Мир, 1993; с. 193-204.

31. Баевский Р. М. Кибернетический анализ процессов управления сердечным ритмом // Актуальные проблемы физиологии и патологии кровообращения. М.: Медицина, 1976; 161 с.

32. Жемайтите Д. И. Вегетативная реакция синусового узла сердца и здоровых и больных. Анализ сердечного ритма. Вильнюс: Москлас, 1982; с. 522.

33. Брук Т. М., Терехов П. А., Осипова Н. В., Зюкин А. В. Эффективность воздействия комплексного применения физических и эргогенных средств на показатели специальной физической подготовленности и анаэробной работоспособности высококвалифицированных спортсменов. Вестник Российской военно-медицинской академии. 2019; 1 (65): 113-9. 
34. Тамбовский А. Н., Сидоренко Т. А., Юрьев Ю. Н., Шурманов Е. Г. Влияние комплекса физиотерапевтических средств на организм спортсменов. Ученые записки университета имени П. Ф. Лесгафта. 2015; (5): 123.

35. Елизаров Н. А. Адаптационная кардиопротекция физическими факторами в лечении и просрилактике ишемической болезни сердца [диссертация]. М., 2007.

36. Еремеева О. В. Физиологические особенности эффектов биоуправления потенциалами мозга у спортсменов с доминированием метаболического модулятора сердечного ритма [диссертация]. Архангельск, 2012.

37. Jo H-G, Schmitd S, Inacker E, Markowiak M, Hinterberger Th.

\section{References}

1. Anokhin PK. Printsipial'nye voprosy obshchey teorii funktsional'nykh sistem. Printsipy sistemnoy organizatsii funktsiy. M.: Nauka, 1973; p. 5-61.

2. Kuznetsova TN, Pavlov SE. Metodika primeneniya fizioterapevticheskikh sredstv (nizkoenergeticheskikh IK-lazerov) V trenirovochnom protsesse plovtsov. Metodicheskaya razrabotka dlya prepodavateley, aspirantov i studentov RGAFK. M.: RGAFK, 1997; 52 p.

3. Dorovskikh VA, Borodin EA, Borodina GP et al. Vliyanie nizkoenergeticheskikh lazerov na svobodnoradikal'noe okislenie glyukozo-6-fosfat degidrogenazy i katalazy eritrotsitov. V sbornike: Materialy Mezhdunarodnogo kongressa "Lazer i zdorov'e-99"; Moskva, 1999; 435-36.

4. Kozel Al, Popov GK. Mekhanizm deystviya lazernogo oblucheniya na tkanevom i kletochnom urovne. Vestnik RAMN. 2000; (2): 41-3.

5. Ulashchik VS. Analiz mekhanizmov pervichnogo deystviya nizkointensivnogo lazernogo izlucheniya na organizm. Zdravookhranenie (Minsk). 2016; (6): 41-51.

6. Potemkin LA. Mediko-biologicheskoe obespechenie i kvantovaya meditsina sporta vysshikh dostizheniy. M.: Izd-vo ZAO "MILTAPKP GIT", 2001; 135 p.

7. Krupatkin Al, Sidorov W. Funktsional'naya diagnostika sostoyaniya mikrotsirkulyatorno-tkanevykh sistem: Kolebaniya, informatsiya, nelineynost'. Rukovodstvo dlya vrachey. M.: LIBROKOM, 2014; $498 \mathrm{p}$.

8. Bogoslova TV. Vliyanie nizkointensivnogo lazernogo izlucheniya na fizicheskuyu rabotosposobnost' studentov instituta fizicheskoy kul'tury [dissertatsiya]. Yaroslavl', 2004.

9. Osipova NV. Sravnitel'naya kharakteristika vliyaniya nizkointensivnogo lazernogo izlucheniya na uroven' fizicheskoy rabotosposobnosti studentov razlichnykh spetsializatsiy sportivnogo vuza [dissertatsiya]. SPb., 2008.

10. Prokopyuk ZN. Ustoychivost' organizma sportsmenov k gipoksi i ee korrektsiya nizkointensivnym lazernym vozdeystviem [dissertatsiya]. Smolensk, 2010.

11. Lifke MV. Dinamika gormonal'nogo statusa sportsmenov razlichnoy kvalifikatsii, vypolnyayushchikh fizicheskuyu nagruzku umerennoy moshchnosti na fone lazernogo vozdeystviya [dissertatsiya]. Kursk, 2009.

12. Volkova AA. Vliyanie nizkointensivnogo lazernogo izlucheniya na funktsional'noe sostoyanie organizma lyzhnikov-gonshchikov [dissertatsiya]. Smolensk, 2011.

13. Pavlov SE., Razumov AN, Pavlov AS. Laser stimulation in medical and biological provision of qualified sportsmen training. M.: Sport, 2017; 536 p.

14. Pavlov SE, Pavlov AS, Petrov AA. Osobennosti dinamiki chrednegruppovykh pokazateley dispersionnykh kharakteristik funktsionirovaniya miokarda khokkeistov, ispol'zovavshikh $v$ predstartovoy podgotovke metod lazernoy stimulyatsii sportivnoy rabotosposobnosti. V sbornike: Olimpiyskiy byulleten' № 15, sost. Mel'nikova NYu, Treskin AV, Leonteva NS, Nikiforova AYu; M.: Izdvo ZAO "Olimpiyskaya panorama", 2014; 247-51.

15. Fokin VF, Ponomareva NV, Kuntsevich Gl. Elektrofiziologicheskie korrelyaty skorosti dvizheniya krovi po sredney mozgovoy arterii zdorovogo cheloveka. Vestnik RAMN. 2013; (10): 57-60.

16. Bollinger $A$. Is high-frequency flux motion due to respiration or to
Meditation and attention: A controlled study on long-term meditators in behavioral performance and event-related potentials of attentional control. International Journal of Psychophysiology. 2016; (99): 33-9.

38. Муллер Т. А., Шилов С. Н. Особенности уровня активации лобной коры и нейрометаболизма головного мозга у детей 7-10 лет с СДВГ. Вестник Новосибирского государственного педагогического университета. 2017; 7 (5): 193-206.

39. Москвин С. В., Кочетков А. В. Эффективные методики лазерной терапии. М.-Тверь: Триада, 2016; 80 с.

40. Павлов С. Е., Павлова Т. Н. Технология подготовки спортсменов. МО, Щелково: Издатель Мархотин П. Ю., 2011; 344 с.

vasomotion activity? In: A. Bollinger et al. Vasomotion and flow motion. Prog Appl Microcirculation. Basel, Karger. 1993; (20): 52-8.

17. Fagrell B. Problems using laser Doppler on the skin in clinical practice. Laser Doppler.- London - Los Angeles - Nicosia: Med Orion Rublishing Company. 1994; 49-54.

18. Fedorovich AA. VEB-kapillyaroskopiya - novye vozmozhnosti monitorirovaniya kapillyarnogo krovotoka $\vee$ kozhe cheloveka. $\vee$ sbornike: Materialy XII mezhdunarodnoy nauchnoy konferentsii "Mikrotsirkulyatsiya i gemoreologiya"; 01-03 iyulya 2019 g.; Yaroslavl': Kantsler 2019: 11.

19. Murrey RK et al. Harper's Biochemistry. Appleton \& Lange, 1996; $700 \mathrm{p}$.

20. Daniolos A, Lerner AB, Lerner MR. Action of light on frog pigment cells in culture. Rigment Cell Res. 1990; 3 (1): 38-43.

21. Tambovskiy AN, Sidorenko TA. Nekotorye rezul'taty primeneniya vnetrenirovochnogo sredstva $v$ protsesse podgotovki grebtsov. Uchenye zapiski universiteta imeni P.F. Lesgafta. 2015; 5 (123): 182-85.

22. Karu TY. Pervichnye i vtorichnye kletochnye mekhanizmy lazernoy terapii. V knige: Moskvin SV, Buylin VA, redaktory. Nizkointensivnaya lazernaya terapiya. M.: Tekhnika, 2000; p. 71-94.

23. Maltsev AP. Mekhanizmy deystviya lazernogo izlucheniya na prokarioticheskie kletki. Mezhdunarodnyy studencheskiy nauchnyy vestnik. 2016; (6): 23.

24. Filippin L, Magalhães PJ, Di Benedetto G et al. Stable interactions between mitochondria and endoplasmic reticulum allow rapid accumulation of calcium in a subpopulation of mitochondria. $J$ Biol Chem. 2003; 278 (40): 39224-34.

25. Schaffer M, Sroka R, Fuchs $C$ et al. Biomodulative effects induced by $805 \mathrm{~nm}$ laser light irradiation of normal and tumor cells. Journal of Photochemistry and Photobiology B: Biology. 1997; 40 (3): 253-57.

26. Eliseenko VI. Mekhanizmy vzaimodeystviya nizkoenergeticheskogo lazernogo izlucheniya IK-spektra $s$ biologicheskimi tkanyami V sbornike: Lazery i aeroiony v meditsine pod red. Evstigneeva AR, Kaplana MA; Kaluga-Obninsk, 1997: 71-2.

27. Krupatkin Al. Neinvazivnaya otsenka tkanevogo dykhaniya u cheloveka $\mathrm{s}$ ispol'zovaniem veyvlet-analiza kolebaniy saturatsii krovi kislorodom i krovotoka v mikrososudakh kozhi. Fiziologiya cheloveka. 2012; 38 (4): 67-73.

28. Gavrilova EA, Larintseva OS. Faktory riska vnezapnoy serdechnoy smerti sportsmenov na raznykh etapakh sportivnoy podgotovki po dannym kardiologicheskogo obsledovaniya. Sportivnaya meditsina: nauka i praktika. 2018; (2): 33-6.

29. Moskvin SV, Fedorova TA, Foteeva TS. Plazmaferez i lazernoe osvechivanie krovi. M.-Tver': OOO «Izd-vo «Triada», 2018; 416 p.

30. Grenner D. Gormony, reguliruyushchie metabolizm kal'tsiya. V knige: R Marri, D Grenner et al, redaktory. Biokhimiya cheloveka, tom 2. M.: Mir, 1993; p. 193-204.

31. Bayevsky RM. Cybernetic analysis of heart rate control processes. Actual problems of physiology and pathology of blood circulation. M.: Medicine, 1976; 161.

32. Zhemaytite DI. Vegetativnaya reaktsiya sinusovogo uzla serdtsa i zdorovykh i bol'nykh. Analiz serdechnogo ritma. Vil'nyus: Mosklas, 1982; p. 522.

33. Bruk TM, Terekhov PA, Osipova NV, Zyukin AV. Effektivnost' 
vozdeystviya kompleksnogo primeneniya fizicheskikh i ergogennykh sredstv na pokazateli spetsial'noy fizicheskoy podgotovlennosti i anaerobnoy rabotosposobnost vysokokvalifitsirovannykh sportsmenov. Vestnik Rossiyskoy voenno-meditsinskoy akademii. 2019; 1 (65): 113-9.

34. Tambovskiy AN. Sidorenko TA, Yurev YuN, Shurmanov EG. Vliyanie kompleksa fizioterapevticheskikh sredstv na organizm sportsmenov. Uchenye zapiski universiteta imeni PF Lesgafta. 2015; (5): 123.

35. Elizarov NA. Adaptatsionnaya kardioprotektsiya fizicheskimi faktorami v lechenii i profilaktike ishemicheskoy bolezni serdtsa [dissertatsiya]. M., 2007.

36. Eremeeva OV. Physiological features of the effects of biofeedback of brain potentials in athletes with dominance of metabolic heart rate modulator [dissertation]. Arkhangelsk, 2012.

37. Jo H-G, Schmitd S, Inacker E, Markowiak M, Hinterberger Th. Meditation and attention: A controlled study on long-term meditators in behavioral performance and event-related potentials of attentional control. International Journal of Psychophysiology. 2016; (99): 33-9.

38. Muller TA, Shilov SN. Osobennosti urovnya aktivatsii lobnoy kory i neyrometabolizma golovnogo mozga u detey 7-10 let s SDVG. Vestnik Novosibirskogo gosudarstvennogo pedagogicheskogo universiteta. 2017; 7 (5): 193-206.

39. Moskvin SV, Kochetkov AV. Effektivnye metodiki lazernoy terapii. M.-Tver': Triada, 2016; 80 p.

40. Pavlov SE, Pavlova TN. Tekhnologiya podgotovki sportsmenov. MO, Shchelkovo: Izdatel' Markhotin PYu, 2011; 344 p. 